\title{
Magma emplacement in transpression: The Santa Olalla Igneous Complex (Ossa-Morena Zone, SW Iberia)
}

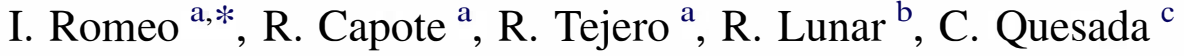 \\ ${ }^{a}$ Departamento de Geodinámica, Facultad de Ciencias Geológicas, Universidad Complutense de Madrid, 28040 Madrid, Spain \\ ${ }^{\mathrm{b}}$ Departamento de Cristalografía y Mineralogía, Facultad de Ciencias Geológicas, Universidad Complutense de Madrid, 28040 Madrid, Spain \\ ${ }^{\mathrm{c}}$ Unidad de apoyo a la Dirección, IGME, 28003 Madrid, and Departamento de Paleontología, Facultad de Ciencias Geológicas, \\ Universidad Complutense de Madrid, 28040 Madrid, Spain
}

\begin{abstract}
The Santa Olalla Igneous Complex, a late-Variscan group of intrusions located in the Ossa-Morena Zone (SW Iberia), has been the focus of a gravity and structural study. The structure outlined by the foliation map is complex, showing two different structural domains: one characterized by vertical, and the other by horizontal, magmatic foliations. The vertical fabrics are restricted to the NE half of the complex, which is in direct contact with a Variscan sinistral strike-slip fault (Cherneca fault) whereas the horizontal fabrics are developed in the SW half of the complex, which is characterized by a horizontal tabular geometry. Gravity modeling indicates that the deeper floor of the plutons is closely related to the NE margin and the Cherneca fault. An emplacement and structural evolution model for this igneous complex is proposed following these structural and gravity results: (1) magma ascent was favored by releasing bends in the trace of the Cherneca fault; (2) when magma reached the present level it intruded to the SW with a horizontal sheet geometry generating the subhorizontal foliation domain; (3) after emplacement, the $\mathrm{NE}$ half of the complex suffered the external tectonic stress field provoked by sinistral motion along the Cherneca fault, subsequently generating the subvertical magmatic foliation domain.
\end{abstract}

Keywords: Pluton structure; Gravity; Magmatism; Variscan orogeny; Transpression; Magma emplacement

\section{Introduction}

Structural analysis in combination with gravity analysis on plutons is a powerful tool in developing emplacement models for magmas in the upper crust. Plutonic rocks usually show preferred orientation of minerals formed during the magmatic state (magmatic fabrics, Paterson et al., 1989, 1998; Park and Means, 1996) or during solid-state strain (deformational fabrics, Paterson et al., 1989; Vernon et al., 2004). The study of the geometry of these fabrics and their comparison with the host rock structure can be used to interpret the emplacement of the magma in a geodynamic context (Paterson and Fowler, 1993; Brown and Solar, 1999; Petford et al., 2000).

\footnotetext{
* Corresponding author. Tel.: +34 67891 9984; Fax: +34 913944845 .

E-mail address: iromeobr@geo.ucm.es (I. Romeo).
}

In the present contribution we report an extensive collection of structural and gravity data obtained from the Santa Olalla Igneous Complex (SOIC), a Variscan group of plutons located in the Olivenza-Monesterio antiform, a major Variscan structure in the Ossa Morena Zone (SW Iberia). Although these kinds of studies have been carried out in several plutons cropping out in the Ossa-Morena Zone (Burguillos-BrovalesValencia del Vetoso-Salvatierra, Brun and Pons, 1981; Bazana granite, Galadí-Enríquez et al., 2003; Castillo granite, Eguíluz et al., 1999; Cardenchosa granite, Simancas et al., 2000), the structure and geometry at depth of the Santa Olalla Igneous Complex still remains unknown.

As this contribution reveals, the Santa Olalla Igneous Complex features a complex and intriguing magmatic structure characterized by two distinct structural domains: (1) a horizontal tabular domain characterized by subhorizontal fabrics 
parallel to the upper and lower intrusive contacts, and (2) a cross-cutting subvertical domain probably related to Variscan tectonic transpressive strain suffered during emplacement. The structural study of this igneous complex is als important because it can be used as a palae-strain indicator of the lateVariscan tectonic regime in this study area. The SOIC, mainly formed by tonalite (Santa Olalla stock) and a small body of gabbronørite (Aguablanca støck, AS), has acquired a special relevance since the recent discovery and expleitation of the $\mathrm{Ni}-\mathrm{Cu}-\mathrm{PGE}$ Aguablanca ore deposit (Lunar et al., 1997; Ortega et al., 2004; Piña et al., in press), lecated in the northern contact of the Aguablanca gabbro-norite with the host rocks. The geochronølogy of the igneous complex is well constrained after the $\mathrm{U}-\mathrm{Pb}$ results obtained by Røme et al. (2006) sh॰wing that the plutonic bodies yield ages within the interval of $340 \pm 3 \mathrm{Ma}$. These ages are similar to other plutons dated in the Olivenza-Monesteriø antiform (Dallmeyer et al., 1995; Bachiller et al., 1997; Casquet et al., 1998; Monter et al., 2000), defining a main Variscan magmatic event, lasting frøm 353 to $329 \mathrm{Ma}$.

The main $\bullet$ bjective of this work is to establish the orientation of the magmatic fabrics in the SOIC obtained using both classical structural geology methods and gravity analysis. Combination of both of these sets of data suggest an emplacement model, that has been discussed considering a geodynamic context characterized by a regional late-Variscan transpressional regime (Ábalos et al., 1991; Ábalos and Cusí, 1995; Eguíluz et al., 2000) indicated by the geochronøløgical data (Røme• et al., 2006).

\section{Geological setting}

The Santa Olalla Igneous Complex is located on the southern limb of the Olivenza-Monesteri antiform (Fig. 1), a majør, WNW-ESE trending Variscan structure, eccupying a central position within the Ossa-Morena Zone (OMZ). The OMZ forms one of the SW divisions of the Iberian Massif, which

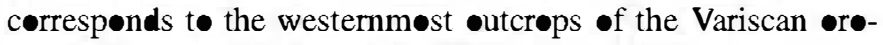
gen in Eurøpe (Ribeirø et al., 1990). The OMZ has als been interpreted as a poly-orøenic terrane accreted to the Central Iberian Zone during the Cadomian orøgeny $(620-530 \mathrm{Ma})$, the suture of which is exposed along the Badajøz-Córdoba shear zone (Quesada, 1990, 1991, 1997; Eguíluz et al., 2000). A subsequent rifting event culminating in formation of a new oceanic crust (Rheic Ocean?) is recorded in the OMZ during Cambr-Ordovician times (Liñán and Quesada, 1990; Expósit• et al., 2003; Sánchez-García et al., 2003). This was followed by a passive margin stage until the onset of the Variscan orogeny in Middle Devonian times. At this point in time, Variscan tectonics started with oblique subduction of the Rheic Ocean beneath the southern margin of the OMZ, where accretion and eventual obduction of eceanic

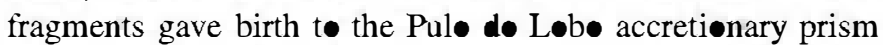
and Beja-Acebuches Ophiølite Munhá et al., 1986; Silva, 1989; Quesada, 1991; Quesada et al., 1994a) and coeval growth of a modest arc on the Ossa Morena plate (Santos et al., 1987). Subduction of the oceanic crust finally led to -blique (sinistral) collision with the South Portuguese Zone, presumably an Avalonian part of already amalgamated Laurussia, which diachronøusly propagated søutheastwards from the Late Devonian to the Late Visean (Ribeir et al., 1990; Quesada, 1991). Subsequent or genesis consisted of sinistral continental subduction of the outer margin of the Søuth Portuguese Zone under the OMZ until its waning in Early Permian times. During the whole orogenic process, the OMZ acted as the upper plate subjected to a transpressional tectonic regime, consequently reactivating the pre-existing Cadomian suture under sinistral wrench conditions (Badajøz-Córdoba shear zone) which now constitutes the northern boundary of the OMZ (Ribeirø et al., 1990; Quesada, 1991; Ábaløs et al., 1991; Quesada and Dallmeyer, 1994).

The structural evelution of the OMZ during the Variscan orogeny was mainly governed by transpressional tectonics throughout its time-span (from the Middle Devonian to the Early Permian). This transpressional regime resulted in the formation of a significant basement invelved, thick-skinned, strike-slip duplex structure, mainly after inversion of the pre-existing horst and graben tectonic compartmentalization acquired during the Cambrian-Ordovician rifting event (Sánchez-García et al., 2003). Internal deformation of each horse is variable and includes several folding and oblique thrust generations, as well as coeval extensional (transtensional) events. In the case of the Olivenza-Monesterio antiform, the basement was shortened by developing an antiformal stack, which tightened in several steps, whereas the Paleozic cover detached from it and initially formed a, typically thin-skinned, SW-verging imbricate fan and large ass ciated recumbent følds (Vauchez, 1975; Quesada et al., 1994b; Expósit॰, 2000). A second følding event, als• SWvergent but characterized by steep axial planes, affected the already deformed thin-skinned imbricate fan after an intervening extensional event, during which søme syn-ørenic basins were formed (e.g., the Terena flysch basin). Finally the overall NW-SE trend of the orogen was reworked by late sinistral strike-slip faults striking $\mathbf{N 5 0}-70^{\circ}$ that generated the cartographic sigmoidal shapes that characterized the tectonic structure of the OMZ (e.g. the Zufre fault, Fig. 2).

Variscan plutonism in the Ossa Morena Zone is characterized by intermediate to acid calc-alkaline compositions ranging from metaluminous tonalite and granodiorite to peraluminøus granite and leucogranite, and by volumetrically minor gabbrøic plutons. The main Variscan plutonic complex in the Olivenza-Monesteri antiform is the sub-circular group - plutons formed by Valencia del Ventosø, Bazana, Brøvales (340 $\pm 4 \mathrm{Ma} \bullet$ btained by $\mathrm{Pb}-\mathrm{Pb}$ Køber on zircons, Mønter et al., 2000; the method is described in Kober, 1987), Valueng• $(342 \pm 4 \mathrm{Ma} \bullet$ btained by $\mathrm{Pb}-\mathrm{Pb}$ Køber on zircons, Monter et al., 2000) and Burguilles del Cerr॰ (330 $\pm 9 \mathrm{Ma}$ -btained by total rock Rb-Sr, Bachiller et al., 1997; $335 \mathrm{Ma}$ -btained by $\mathrm{Ar}-\mathrm{Ar}$ on amphibøle, Dallmeyer et al., 1995; $338 \pm 1.5 \mathrm{Ma}$ obtained by $\mathrm{U}-\mathrm{Pb}$ on allanite, Casquet et al., 1998). Spatially separated frøm this group of plutons, $50 \mathrm{~km}$ to the SE, is the Santa Olalla Igneous Complex, the subject -f this study $(340 \pm 3 \mathrm{Ma}$ obtained by $\mathrm{U}-\mathrm{Pb}$ on zircons, 


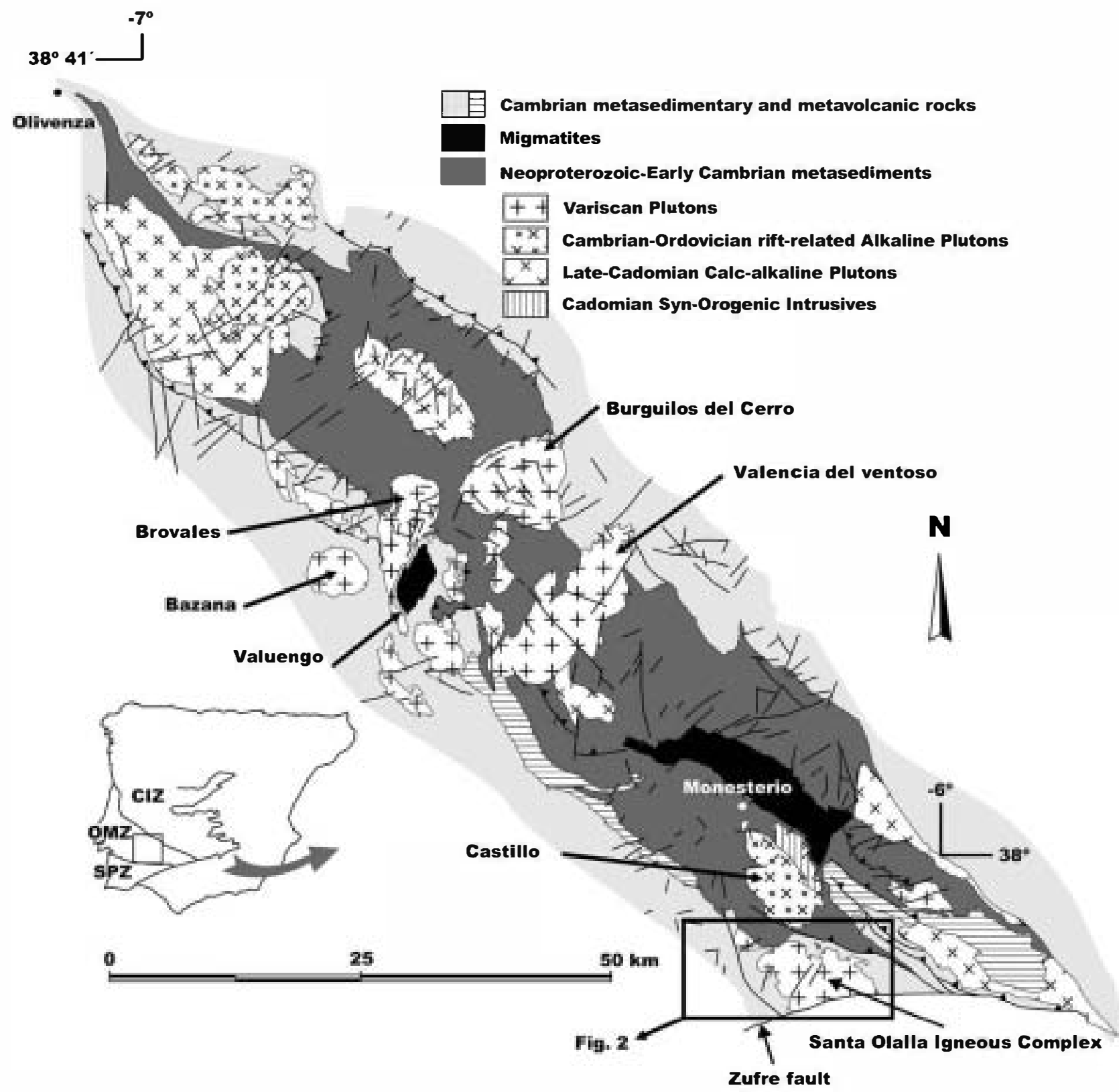

Fig. 1. Plutonic rocks in the Olivenza-Monesterio antif orm. The location of Fig. 2 that corresponds to the Santa Olalla Igneous Complex is shown. Inset: Southern divisions of the Iberian Massif (CIZ, Central Iberian Zone; OMZ, Ossa-Morena Zone; SPZ, South Portuguese Zone).

Røme• et al., 2006). A later extensiønal Permian event generated a set $\bullet$ NW-SE-trending diabasic dykes $(250 \pm 5 \mathrm{Ma} \bullet b-$ tained by total rock K-Ar, Galind॰ et al., 1991) that can be found in numerous localities across the OMZ.

\section{Geology of the Santa Olalla Igneous Complex}

\subsection{Igneous rocks}

The Santa Olalla Igneous Complex is formed by twø main plutons: the Santa Olalla stock and the Aguablanca stock (AS) (Fig. 2). The Santa lalla stock (Eguiluz et al., 1989), the largest pluton of the complex, is comprised primarily of hornblende-biøtite diorite and quartz-diorite in the northern and northeastern area grading to a main tonalitic facies in the center that grades to a small body of monzegranite towards the søuthern børder. Alsø søme small leucøgranite bødies appear scattered throughout this stock. This dispøsition of the igneøus facies has been interpreted as due to a reverse compositional zøning (Velasc•, 1976; Casquet, 1980). Towards the NW there is a mafic apøphysis (Sultana) (Apalategui et al., 1990), c॰mposed of hornblende-biotite tonalite and quartz-diorite.

The Aguablanca stock, a mafic subcircular pluton, crops out in the northern part of the complex. It is composed of phlogøpite-rich gabbrøn॰rite and norite, grading, in the søuth, to diorite. This intrusion has undergøne significant endoskarn processes along the northern boundary induced by contact with marbles in the Cambrian host rocks (Casquet, 1980). 


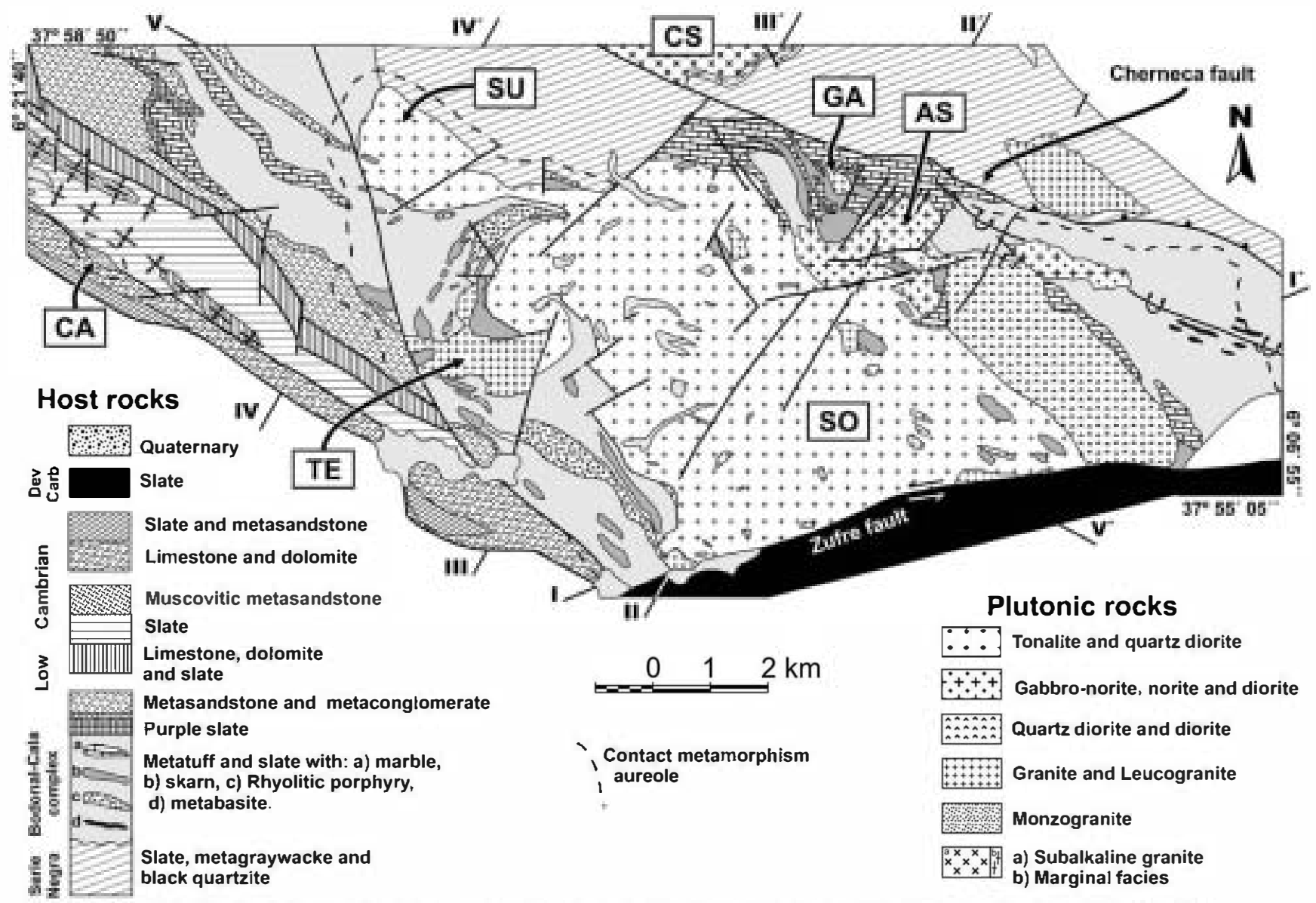

SO: Santa Olalla stock, AS: Aguablanca stock, SU: Sultana, TE: Teuler, GA: Garrote, CA: Cala, CS: Castillo

Fig. 2. Geological map of the Santa Olalla Igneous Complex. The location of the igneous bodies and gravity profiles are shown.

The Aguablanca $\mathrm{Ni}-\mathrm{Cu}-\mathrm{PGE}$ deposit (Lunar et al., 1997; Ortega et al., 1999, 2000, 2004; Tornos et al., 1999, 2001; Casquet et al., 2001; Piña et al., in press) is hosted by the Aguablanca gabbronorite and is closely associated with a subvertical (dipping $70-80^{\circ} \mathrm{N}$ ), funnel-like magmatic breccia (250-300 $\mathrm{m}$ wide $\mathrm{N}-\mathrm{S}$ and up t॰ $600 \mathrm{~m}$ long $\mathrm{E}-\mathrm{W}$ ) situated in the northern part of this pluton. The breccia is comprised of barren or slightly mineralized ultramafic-mafic cumulate fragments enveloped by hornblende and phlogøpite-rich gabbronorite containing disseminated and semi-massive $\mathrm{Ni}-\mathrm{Cu}-\mathrm{Fe}$ magmatic sulfides.

Three granitic intrusions (Garrote, Teuler and Cala) can als be found arøund the igneøus complex. The Garrote intrusion is a hornblende-bearing syenitic granite located near the northern boundary of AS. The Teuler intrusion is located in the W of the Santa Olalla stock; and is a fine-grained biotite monzogranite that generates a magnesian skarn with a magnetite mineralization (Tornos et al, 2004). The Cala monzogranite is a very small øutcrop located abøut $8 \mathrm{~km}$ towards the W from the Santa Olalla stock (Fig. 2), and hosts the magnetite mineralization of Minas de Cala (Døetsch and Rømerø, 1973; Casquet and Velasc•, 1978; Velasc and Amigé, 1981).

The gechronølogy of the SOIC has been recently established (Røme• et al., 2006) by $\mathrm{U}-\mathrm{Pb}$ technique on zircons and with the exception of the Cala granite $(352 \pm 4 \mathrm{Ma})$, which represents an $\bullet$ lder intrusion, the bulk of samples yield ages clustering around $34 \pm 3 \mathrm{Ma}$ : the Santa Olalla tonalite $(341.5 \pm 3 \mathrm{Ma})$, the Sultana hornblende tonalite (341 \pm $3 \mathrm{Ma}$ ), a mingling area at the contact between the Aguablanca and Santa Olalla stocks ( $341 \pm 1.5 \mathrm{Ma})$, the Garrote granite $(339 \pm 3 \mathrm{Ma})$, the Teuler granite $(338 \pm 2 \mathrm{Ma})$, and dioritic dykes frøm the Aguablanca støck $(338.6 \pm 0.8 \mathrm{Ma})$.

Structurally, the SOIC is located in a wedge limited by twe main faults: the Cherneca Fault, a SW-verging structure trending parallel to the general Variscan direction in this zone (N120) with a reverse and sinistal kinematics (Fig. 2), and the Zufre fault, a late $\mathbf{N} \mathbf{8 0 ^ { * }}$ sinistral strike-slip fault.

\subsection{Host rocks}

The Santa Olalla Plutonic Complex intrudes int $\bullet$ tw $\bullet$ different stratigraphic units, both affected by low-grade regional metamorphism. In the northwest margin the host røcks are comprised of alternating pyrite-bearing black-slate and meta-graywacke with thin intercalations of meta-v•lcanic rocks and black quartzite (Tentudia succession), part of the Neøprøterøzic Serie Negra (Eguíluz, 1988). Tøwards the $\mathrm{N}, \mathrm{E}$ and $\mathrm{W}$ the igneous rocks intrude inte the Early 
Cambrian Bedonal-Cala complex (Eguíluz, 1988), which lies unonformably above the Tentudia succession, and it is

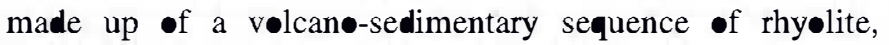
crystal tuffs, fine tuffs, cinder slates, and coarse-grained

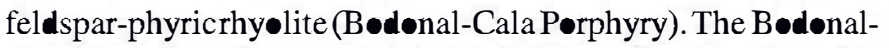
Cala Complex alsø contains intercalations of carbønate røcks, more abundant towards the top, producing an exøskarn characterized by garnetite, marble and calc-silicate rocks along the contacts with igneøus rocks (Casquet, 1980).

The høst rocks are affected by a regional metamorphism of low to very low grade and show an intense superimposed contact metamorphism. The metamorphic aure le is more than $2 \mathrm{~km}$ wide, and consists of albite-epidote facies in the external zone grading int $\bullet$ hypersthene hornfels facies in the internal 200 meters.

The Santa lalla støck contains numerøus røof pendants $\bullet$ the høst røck, scattere thrøughøut the igneøus bødy, implying that the upper contact has undergone only slight erøsion.

\section{Magmatic fabric}

The Santa Olalla Igneøus Complex was completely deformed during the magmatic phase, and no evidence of a significant sub-solidus strain has been found. Considering that quartz is the last crystallizing phase and that only quartz shows undulose extinction and subgrains, one can interpret a weak sub-sølidus deformation. Nevertheless, plagioclase, biotite and hornblende remain undeformed. The igneous fabrics are generally evidence at mes-scale by the orientation of plagi $\bullet$ clase (1-4 mm long) forming magmatic føliations favored by the planar habit of this mineral. Alsø, as a secondary mineralforming fabric, the biøtite seems to be occasionally oriented, showing planar fabrics defined by the preferred orientation -f its planar habit. More mafic rocks (i.e. gabbronorites and quartz-diorites) alsø show magmatic føliations defined by the preferred orientation of plagioclase. However, in the møre mafic facies pyrøxene als plays a røle during the fabric generation. In these cases pyroxene usually displays the same planar fabric as the plagioclase, defined by the randomly oriented elongated axes of the pyroxenes internal to the foliation plane. Only at tw $\bullet$ localities a magmatic lineation has been $\bullet b-$ served defined mainly by the randomly oriented elongated axes of the pyroxenes included in the foliation plane. Taken together these data may correspond to the ascent area of the Aguablanca gabbronorites surrounding the $\mathrm{Ni}-\mathrm{Cu}-\mathrm{PGE}$ mineralization.

In order t• study this magmatic structure, 223 measurement stations scattered along the SOIC area were analyzed. The magmatic foliation map and the foliation trajectories are shown in Fig. 3a and b, respectively. The foliation map reveals a consistent $\bullet$ rientation pattern, where tw $\bullet$ different structural domains can be distinguished: a NE area, striking parallel to the long axis of the stock, where the foliations show dominantly a NW-SE strike and vertical or high angle dips, and the SW area where foliations are predominantly of low dip angle or horizontal (see the distribution on the dip values $\bullet$ the foliation in the stere plots shown in Fig. 3a).
The vertical $\left(\mathrm{N} 140^{\circ}\right.$ striking) structural domain of the NE margin of the Santa lalla støck is concordant with the trajec-

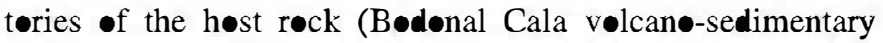
complex). The magmatic foliation rajectories of the subvertical domain show a unique disposition containing tw• main ori-

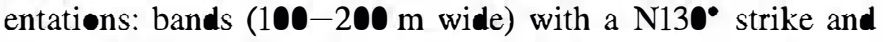
a dip $\bullet 9^{\circ}$ to $70^{\circ}$ to the søuth, and, in between those bands, -blique foliations with a $\mathrm{N}^{\circ} 55^{\circ}$ strike and vertical dips. As seen in the foliation trajectory map this pattern defines rhomboidal geomeries (A in Fig. 3b).

Alternatively, the sub-horizontal structural domain $\bullet$ ccupies the SW area of the SOIC. By analyzing the relationships between the rajectories within the host rock and the igneous complex four important conclusions can be drawn: (1) the magmatic foliations are dominantly discordant with respect to the intrusive contact, but the host rock structure is dominantly parallel to the pluton margins; (2) a riple point in the host rocks rajectories with an asymmetric disposition with respect to the long axis of the complex has been found (B in Fig. 3b); (3) the transition between both domains (vertical and sub-horizontal) is mainly characterized by medium dips $\left(60-30^{\circ}\right)$ to the $S W$ and a $N 140^{\circ}$ strike parallel to the vertical domain; (4) in this ransition area and alse in the sub-horizontal domain, narrow bands with vertical foliations

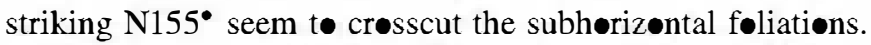

The Aguablanca stock exhibits a complex structure dominated by a vertical føliation, parallel to the $\mathrm{N}$ and $\mathrm{NW}$ contacts -f the stock, with vertical lineations in the northern area where the gabbronorite appears surrøunding the $\mathrm{Ni}-\mathrm{Cu}-\mathrm{PGE}$ mineralize breccia pipes. Alternatively the center of Aguablanca is characterized by predominately horizontal foliations. Nevertheless, to the south, the fabrics show a $\mathrm{N}^{\circ} 0^{\circ}$ strike and high dip angle towards the NE that seems appear t॰ be linked to the magmatic structure of the surrounding tonalite characterized by similar orientations.

Comparison of the relations of each main fault (Zufre and Cherneca) with the general igneous structural pattern produces very different results. On one hand the $\mathrm{Zu}$ fre fault has a clear post-intrusive character as it appears to cut all the foliation rajectories of the tonalite. On the other hand, the Cherneca fault shows a significant parallelism with the subvertical domain of the Santa Olalla tonalite and the Aguablanca northern border.

\section{Gravity study}

\subsection{Gravity survey}

A gravity survey was carried out in an area of abøut $230 \mathrm{~km}^{2}$, covering the entire SOIC as well as the Cala granite separated from the SOIC abøut $8 \mathrm{~km}$ to the W, using 315 gravity stations in total. Measurements were taken at evenly distributed localities with an average density of 1.37 stations per $\mathrm{km}^{2}$. The measurements were performed using a LaCoste \& Rømberg G-meter 953 from Universidad Complutense de Madrid (UCM) with a nominal precision of $\pm 0.01 \mathrm{mGal}$. A station løcated in Monesteriø, Badajøz, 

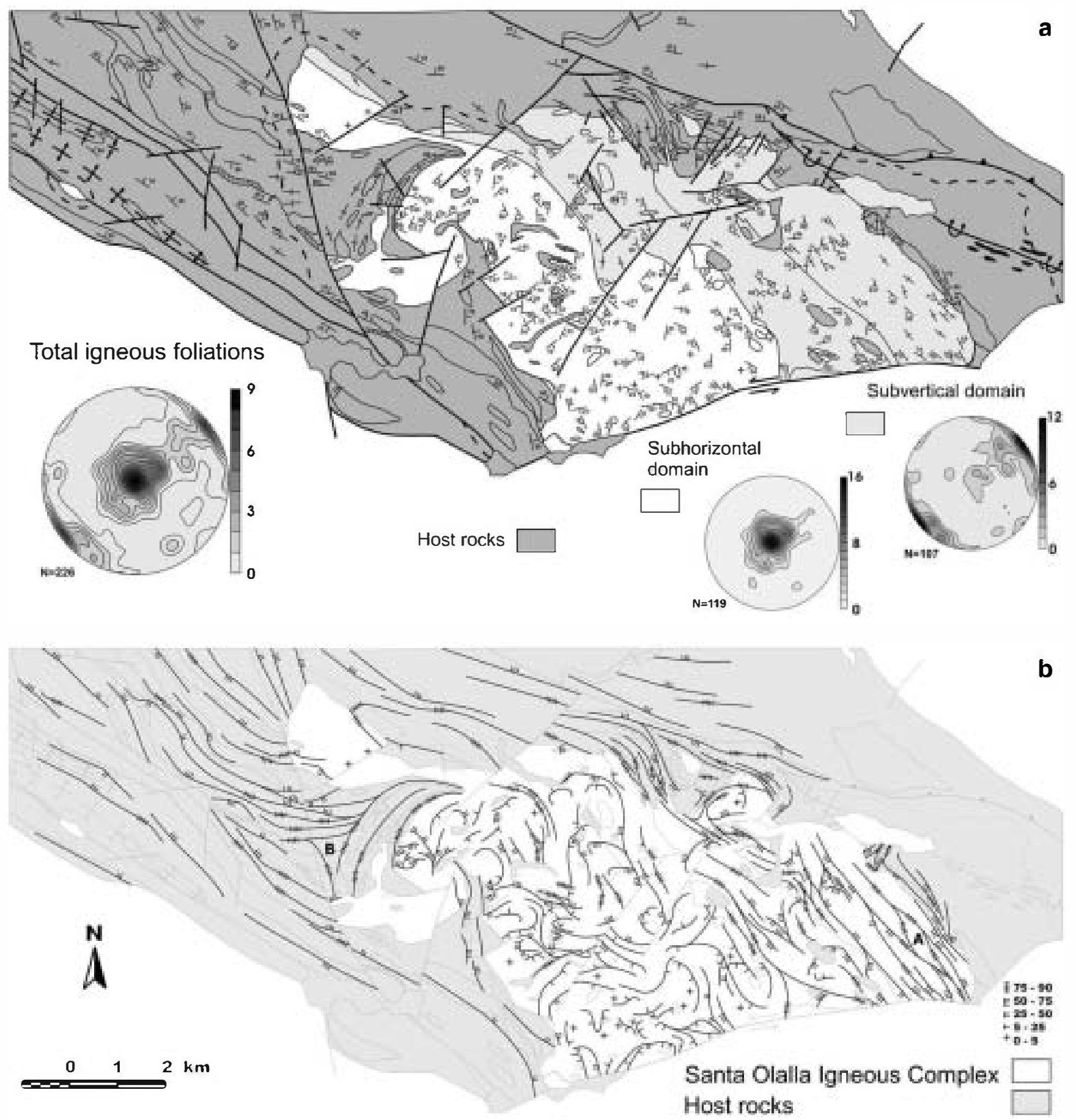

Fig. 3. (a) Magmatic foliation map, with the division in stuctural domains. Lower-hemisphere equal-area projections of the magmatic foliations from each stuc-

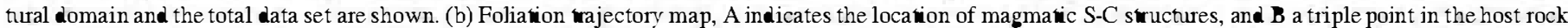
structure.

(absølute gravity: $979862.77 \mathrm{mGal}$ ) was used as gravity base station (linked to the Spanish Geographic Institute base station at Fuente de Cantos, Badajøz). Elevations were determined, where possible, from geodetic bench-marks but als using a digital baremetric altimeter with a precision -f $\pm 0.2 \mathrm{~m}$. Paths between stations with known geodetic elevation never exceeded 2 hour intervals in order to minimize the effect of barometric variations in elevation estimation errørs. This procedure enables $\bullet$ ne t॰ estimate error margins of $\pm \mathbf{0} .1 \mathrm{mGal}$.

The gravity measurements were, corrected for Earth-tide effects, free-air and Bouguer reductions were applied and ter-

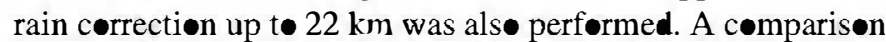
of $10 \%$ duplicate gravity measurements revealed a røot mean

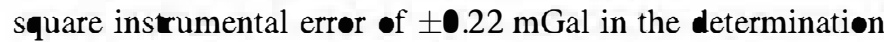
-f the •bserved g. The density value used in the Bøuguer 
reduction and terrain corrections was $2.75 \mathrm{~g} \mathrm{~cm}^{-3}$, matching the average density of the rocks in the study area. Kriging was used to interpølate the Bøuguer an॰maly values in a square grid of $250 \mathrm{~m}$.

\subsection{Bouguer anomaly map and residual anomaly map}

The Bouguer anomaly (Fig. 4a) decreases from ESE to WNW with an average gradient of $1.4 \mathrm{mGal} \mathrm{km}^{-1}$ (from 30 to $11 \mathrm{mGals}$ ). As seen in Fig. 4, is anomaly lines are subparallel the Zufre fault trend. The maximum Bøguer values are in direct association with the SE block of the Zu fre fault where the South Portuguese Zone was approached by a sinistral movement. In the north of the map the minimum values are found in the proximities of the Castill granite, a subalkaline, tw• mica granite dated at $502 \pm 8 \mathrm{Ma}(\mathrm{Pb}-\mathrm{Pb}$ Køber on zircons, Monter et al., 2000). Apart from these general considerations the Bouguer anomaly pattern does not correlate clearly with the mapped structures and plutons, therefore it must be related with deep seated sources.

In order to analyze shallower sources a residual anomaly map was calculated. A Bouguer map (kindly lent by Sánchez-Jiménez, 2003) with a square grid of $5000 \mathrm{~m}$ was used as a regional anomaly map. It covers all the $\mathbf{O M Z}$ with $\mathbf{0 . 0 7}$ stations per $\mathrm{km}^{2}$. This low data density generates a map dominated by large wavelengths which, in our case, can only be caused by deep-seated sources. These regional data were subracted from our Bøuguer map t॰ obtain a residual anomaly map.

This residual map (Fig. 4b) features tw• main anømalies, a gravity high (5 mGals) and a gravity low ( $-4 \mathrm{mGals})$. The main gravity high is located in the western part of the map, covering the area dominated by the Sultana hornblende tonalite and the host rocks of the Bodonal-Cala volcanosedimentary Complex. The main gravity low is located in the SE margin of the Santa Olalla tonalite where it is cut by the Zufre fault. This minimum corresponds to the largest part of the Santa Olalla stock. Other local gravity highs can be found on the Aguablanca gabbronorite and the surrounding skarn rocks, and als to the NE margin of the Santa Olalla stock where the dominant lithology is quartzdiorite in contact with a $200 \mathrm{~m}$ wide marble band. The residual anomaly patterns indicate that density contrasts are mainly controlled by the igneous rocks rather than by the structure of the host rocks. Gravity highs and lows can be correlated to mapped plutons or to postulated intrusions under the present erosion level.
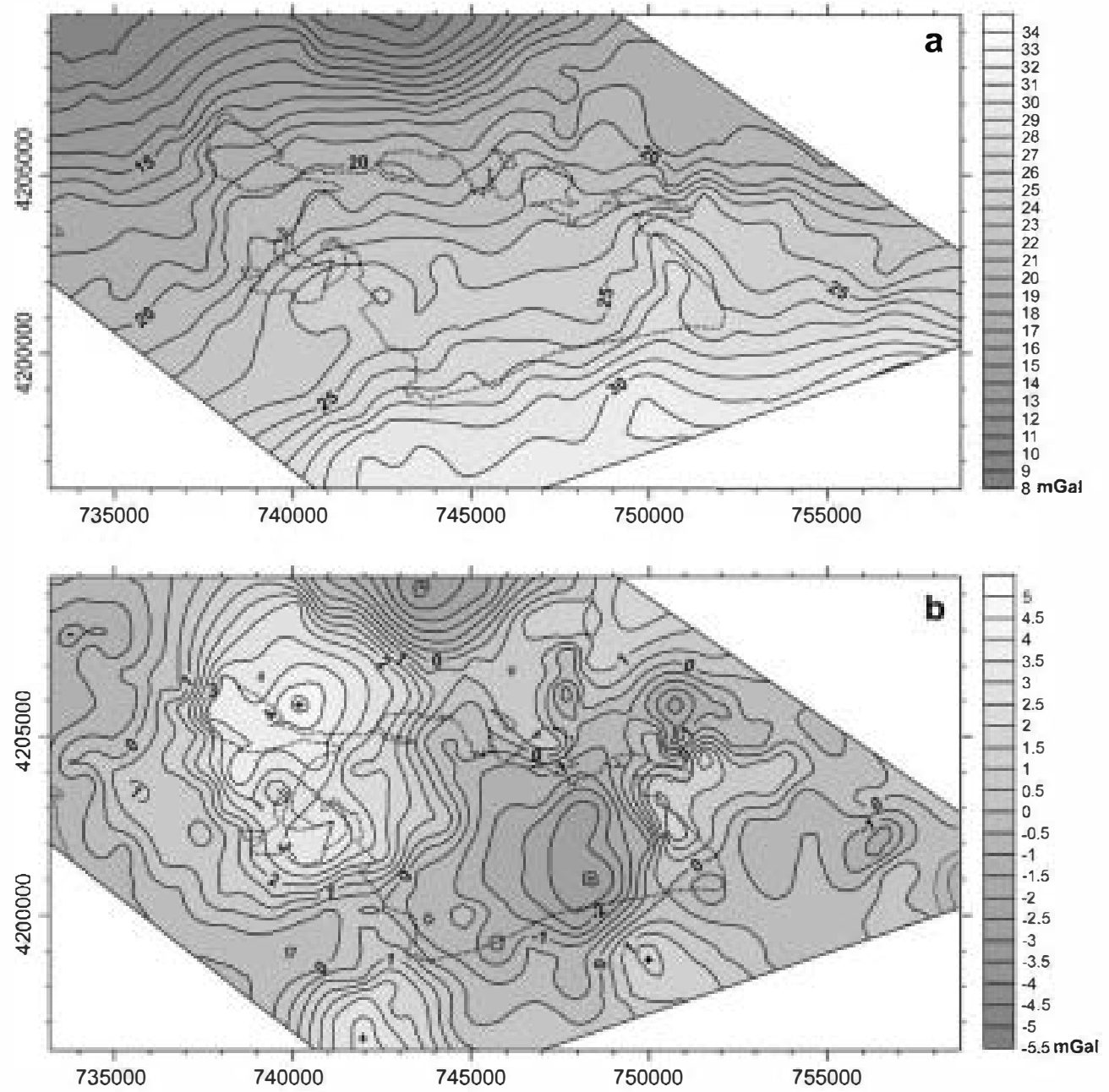

Fig. 4. (a) Bouguer anomaly map. (b) Residual anomaly map. Location of the Santa Olalla Igneous Complex is showr. 


\subsection{Density determinations and modeling}

Two hundred and forty density measurements of the SOIC rocks and the host rocks where performed. Histograms with the results for six lithologies and the total data are shown in Fig. 5. It was not possible to obtain fresh samples of the slates and tuffs of the Bodonal-Cala Complex and the slates of the Serie Negra, that could yield reliable density values; so their densities have been inferred during the modeling process.

The models where performed using the software GM-SYS $4.9 .39 \mathrm{~b}$ by Geosoft. The methods used to calculate the gravity model response are based on the methods of Talwani et al. (1959) and Talwani and Heirtzler (1964) and make use of the algorithms described in Won and Bevis (1987). GM-SYS uses a $23 /{ }_{4} \mathrm{D}$ approach, where blocks are defined by a prism with a different width located perpendicularly in front and behind of the model plane. This approach $\left(2 \frac{3}{4} \mathrm{D}\right)$ also permits variations in the density contrast in the out-of-model prism contacts in front of and behind of the model plane. Structural data, geological cross-sections and density estimations were used to constrain gravity model geometry. Where gravity anomaly does not fit with surface geological data, new bodies were introduced taking into consideration the most plausible hypothesis.
Five $23 / 4 \mathrm{D}$ models were performed in order to constrain the $3 \mathrm{D}$ geometry of the plutonic complex Fig. 6 . The gravity profile $\mathrm{I}-\mathrm{I}^{\prime}$ is parallel to the Zufre fault crossing the Santa Olalla tonalite in its wider part. The gravity profiles II-II', III-III' and IV-IV ${ }^{\prime}$ are disposed perpendicular to the Variscan structures, and the gravity profile $\mathrm{V}-\mathrm{V}^{\prime}$ is disposed parallel to the Variscan trend.

The gravity profile $\mathrm{I}-\mathrm{I}^{\prime}$ is characterized by a gravity low. A thickening of the tonalite in the gravity low has been modeled and this model shows the thickest values for the Santa Olalla tonalite reaching a depth of $3630 \mathrm{~m}$ below sea level. In order to justify the presence of short-wavelength anomalies, a heterogeneous density for the Santa Olalla stock can be considered. As the geological map shows (Fig. 2), the Santa Olalla tonalite presents scattered outcrops of granites, which are especially abundant in the southern part of the stock. The presence of these granite bodies has been considered to adjust the shortwavelength anomalies. To further constrain and investigate this problem, a main body of leucogranite near the surface, with a similar density of that cropping out at Santa Olalla village, has been modeled. Towards the ENE the residual gravity shows a local high over a quartzdiorite band of the Santa Olalla Stock. An average density of $2.85 \mathrm{~g} \mathrm{~cm}^{-3}$ and maximum depth of $3900 \mathrm{~m}$ below sea level has been obtained by adjusting the anomaly caused by this mafic band.
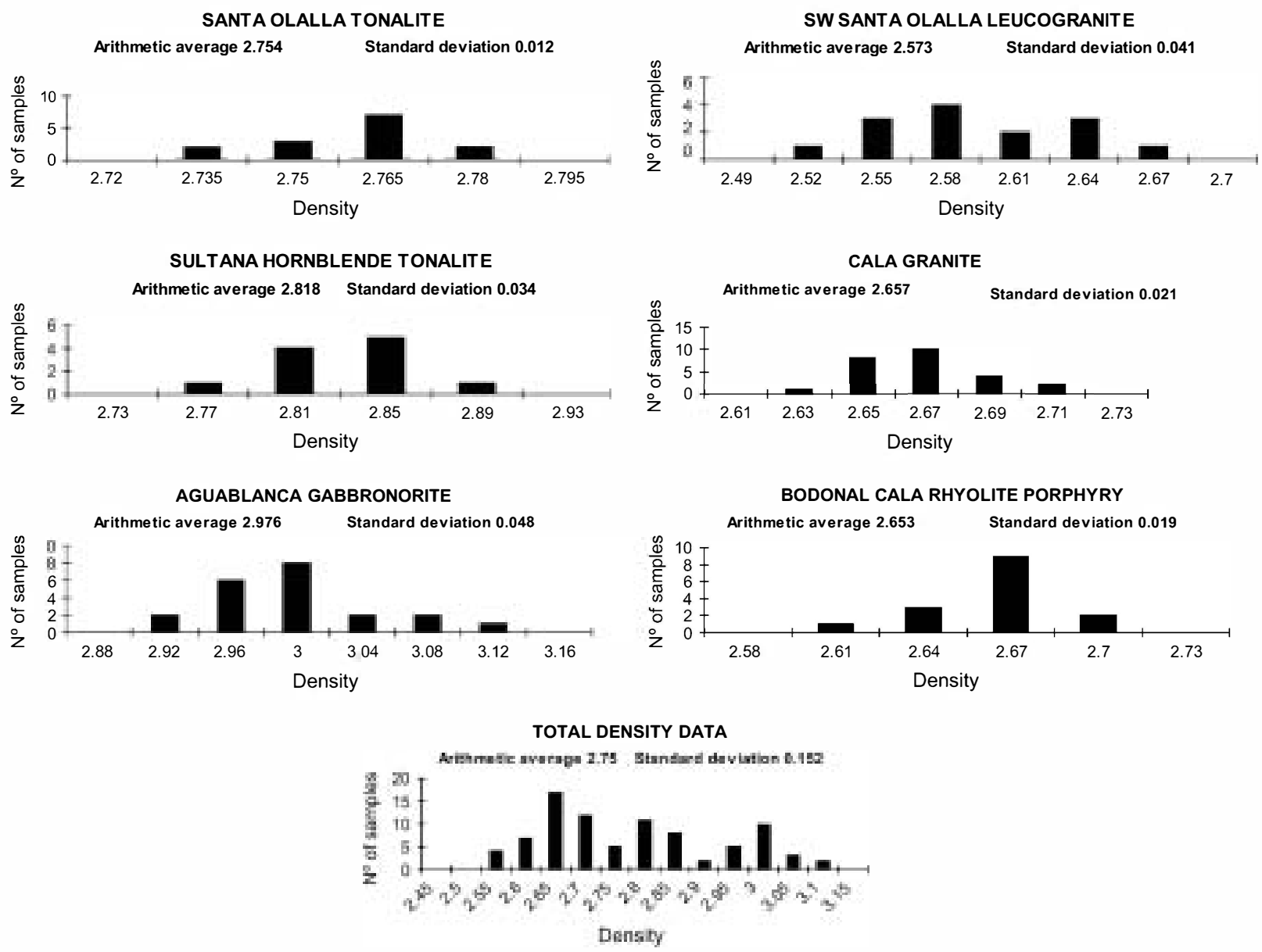

Fig. 5. Histograms of densities $\left(\mathrm{g} \mathrm{cm}^{-3}\right)$ with the arithmetic average and the standard deviation for each lithology and for the whole data set. 

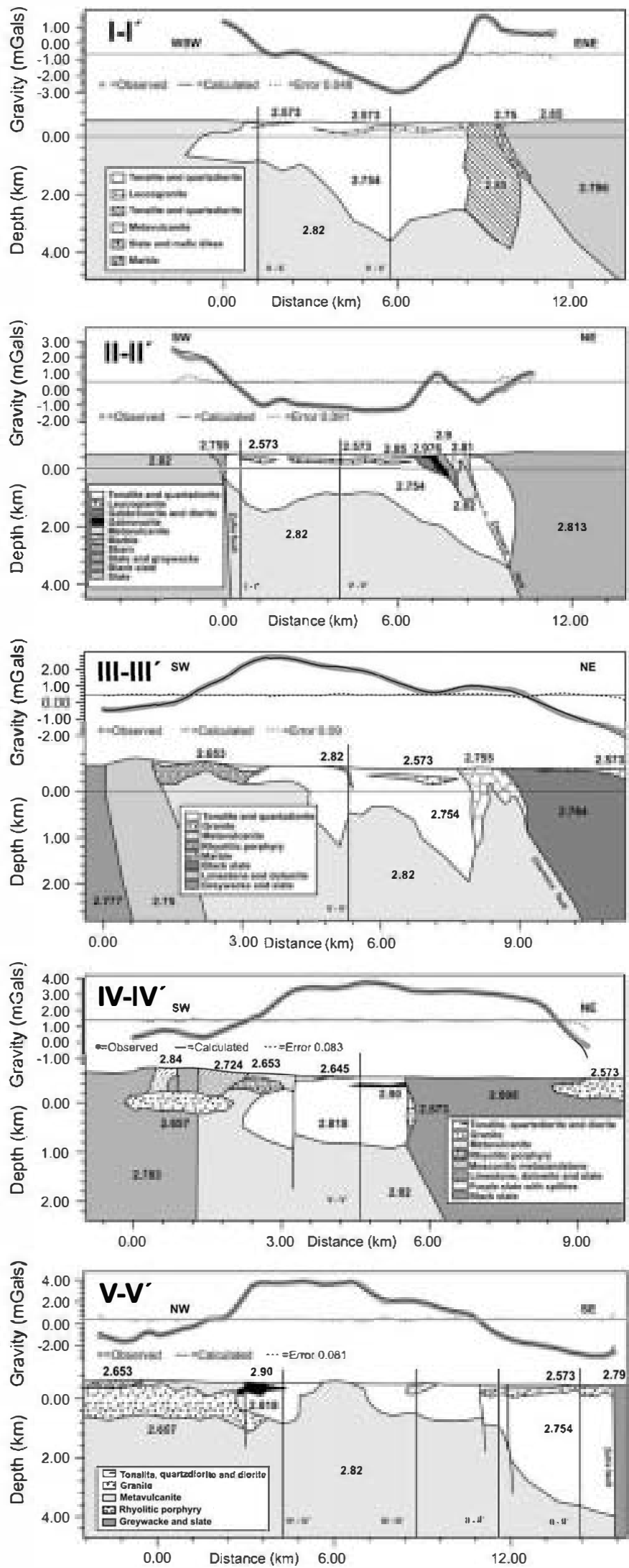

Fig. 6. Gravity models perforned using GM-SYS 4.9 .39 by Geosoft
The gravity profile $-\mathbf{I}^{\prime}$ is characterized by a general flat bøtt $\bullet$ gravity low that covers the entire section. In the NE part of the gravity low a local maximum appears, which is generated by the Aguablanca stock and the associated garnetite-rich skam. The Santa Olalla tonalite is characterized by a $1.5 \mathrm{~km}$ thick sheet geometry with a root area in the north matching the Cherneca fault where the deepest contact between Santa Olalla and the host rock is $3450 \mathrm{~m}$ below sea level. The Santa Olalla stock shows the continuation of the low density body near the surface that was described in model I-I' . Aguablanca has been modeled with tw॰ different bødies: a northern one dominated by gabbronorite with an average density •f $2.967 \mathrm{~g} \mathrm{~cm}^{-3}$, and a søuthern one of quartzdiorite and plagioclase-rich gabbronorite with an average density of $2.85 \mathrm{~g} \mathrm{~cm}^{-3}$. The skarn dominated by garnetite was modeled with a density of $2.9 \mathrm{~g} \mathrm{~cm}^{-3}$. Other bodies correspond to the marbles and the metavulcanites of the Bødonal-Cala complex with average densities of $2.81 \mathrm{~g} \mathrm{~cm}^{-3}$ and $2.82 \mathrm{~g} \mathrm{~cm}^{-3}$ respectively. Low values of residual gravity appear, again, in the zone of the Cherneca fault, which should be caused by any low-density rock under the outcropping host rock. The model also shows that the Santa Olalla tonalite appears under the Aguablanca stock and it is very near to the surface in the area $\bullet$ the Cherneca fault. The presence of these low-density igneøus rocks in this area is supported by the outcrop of the Garrote Granite.

The thickness of the Santa Olalla stock is considerably reduced in the model $\mathbf{E}-\mathbf{I} \mathbf{I}^{\prime}$. This gravity profile presents a maximum in the southern part caused by the outcropping host rocks. In the southern termination of the Santa Olalla stock the average modeled thickness of the sheet is $320 \mathrm{~m}$ while in the rest of the model it shows an average thickness of $1100 \mathrm{~m}$. A local gravity low in the north part has been interpreted as a result of the thickest area of the Santa Olalla t•nalite in this profile, with a maximum depth for the contact with the host rocks of $1950 \mathrm{~m}$ below sea level.

The gravity profile IV-IV' crosses the entire Sultana hornblende tonalite $\left(2.818 \mathrm{~g} \mathrm{~cm}^{-3}\right)$ and features a flat topped gravity high on the Sultana intrusion and the northern Serie Negra ๑utcrop. For this intrusion, a $1360 \mathrm{~m}$ thick elliptical section has been modeled. In this model, søe shallow small bødies as density heterogeneities within the Sultana hørnblende tonalite have been introduced to account for short-wavelength anomalies. The gravity high is mainly generated by the density contrast between: the central area dominated the high density rocks of the Sultana hornblende tonalite and the Serie Negra, and the profile terminations dominated by low density røcks. These løw-density røcks are: the Castillø granite in the northern termination and a granitic body that can be related the neighbor Cala granite $\left(2.657 \mathrm{~g} \mathrm{~cm}^{-3}\right)$ in the southern termination.

Finally, the gravity profile $\mathbf{V}-\mathbf{V}^{\prime}$, striking parallel to the Variscan structures (N120*) was modeled by assembling the gravity models previously described. This profile is characterized by a large flat topped maximum, located on the Sultana intrusion, and the host rocks to the SE. Towards the SE termination the residual anømaly decreases significantly, 
implying the thickening of the Santa Olalla Stock towards the Zufre fault. This evidence suggests that the thickening $\bullet$ the Santa Olalla tonalite is controlled by the fault set striking N40 (Fig. 2). The gravity decrease towards the NW is controlled by the same low density $\left(2.657 \mathrm{~g} \mathrm{~cm}^{-3}\right)$ body described in the gravity profile IV-IV' which can be related to the Cala Granite.

\section{Discussion}

Gravity models shøw a thickening of the Santa lalla støck close to the Cherneca and Zu fre faults coinciding with the area where subvertical magmatic foliations striking parallel to the Cherneca fault are developed. Towards the SW, where subhorizontal foliations characterize the pluton fabric, the tonalite is thinner and exhibits a subhorizontal sheet geømetry. Depth variations of the Igneous Complex are shown in Fig. 7. Structural data collected from the surface were extrapolated at

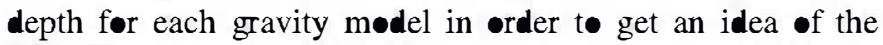
3D foliation structure (Fig.7).

The Santa Olalla Igneous Complex was emplaced during

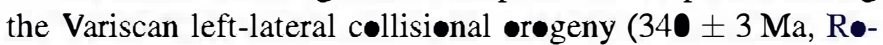
me et al., 2006) in a shallow structural level $(2-4 \mathrm{~km}$; Casquet, 1980) where the host rocks have a low to very low regional metamorphic grade. This relatively cold and low pressure envirønment promoted a partial decoupling between the magma and the host rock structure, as shøwn by the foliation trajectory map (Fig. 3b). This partial mechanical decoupling is especially evident in the $S W$ border of the subhorizontal domain, where the planar structure of the pluton (subhorizontal) is n॰t parallel to that of the høst rocks (subvertical). Nevertheless, the parallelism of the subvertical domain with the structure of the høst røcks at the NE margin reveals the existence $\bullet$ a mechanical coupling in this area. Although the host rock shows foliations generally parallel to the intrusive contact, which could suggest a partially forced emplacement, the presence $\bullet$ numerøus røof pendants of høst røcks probably implies that "stoping" played an important role during the last stages -f emplacement.

As evidenced by Paterson et al. (1998), in magmatic systems mechanically decoupled from their høst røcks, structural patterns may result frøm strain during internally driven flow, filter pressing or porous flow in relatively static chambers, or by final increments of stain during emplacement. The ranspressional environment deduced from geølogical and structural evidence throughout the $O M Z$, supported by the geøchrøn॰logical data, indicates that the SOIC prøbably suffered similar tectonic stresses during its emplacement and crystallization. The structure of the SOIC, as shown in previ-

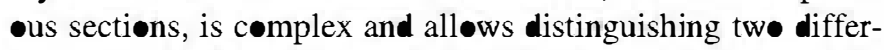
ent areas, dominated by vertical and horizontal føliations. The first decoupled and the second mechanically coupled to the løcal høst røck structure.

The SW area of the complex has both a subhorizontal sheet gemetry and a subhorizontal magmatic føliation exhibiting magmatic fabrics parallel to the upper and lower intrusive contacts. The formation of these horizontal fabrics can be explained by magmatic flow along the sheet during intrusion. There are however $\bullet$ ther hypotheses, such as the one proposed for concentric fabrics by Paterson et al. (1998), in which

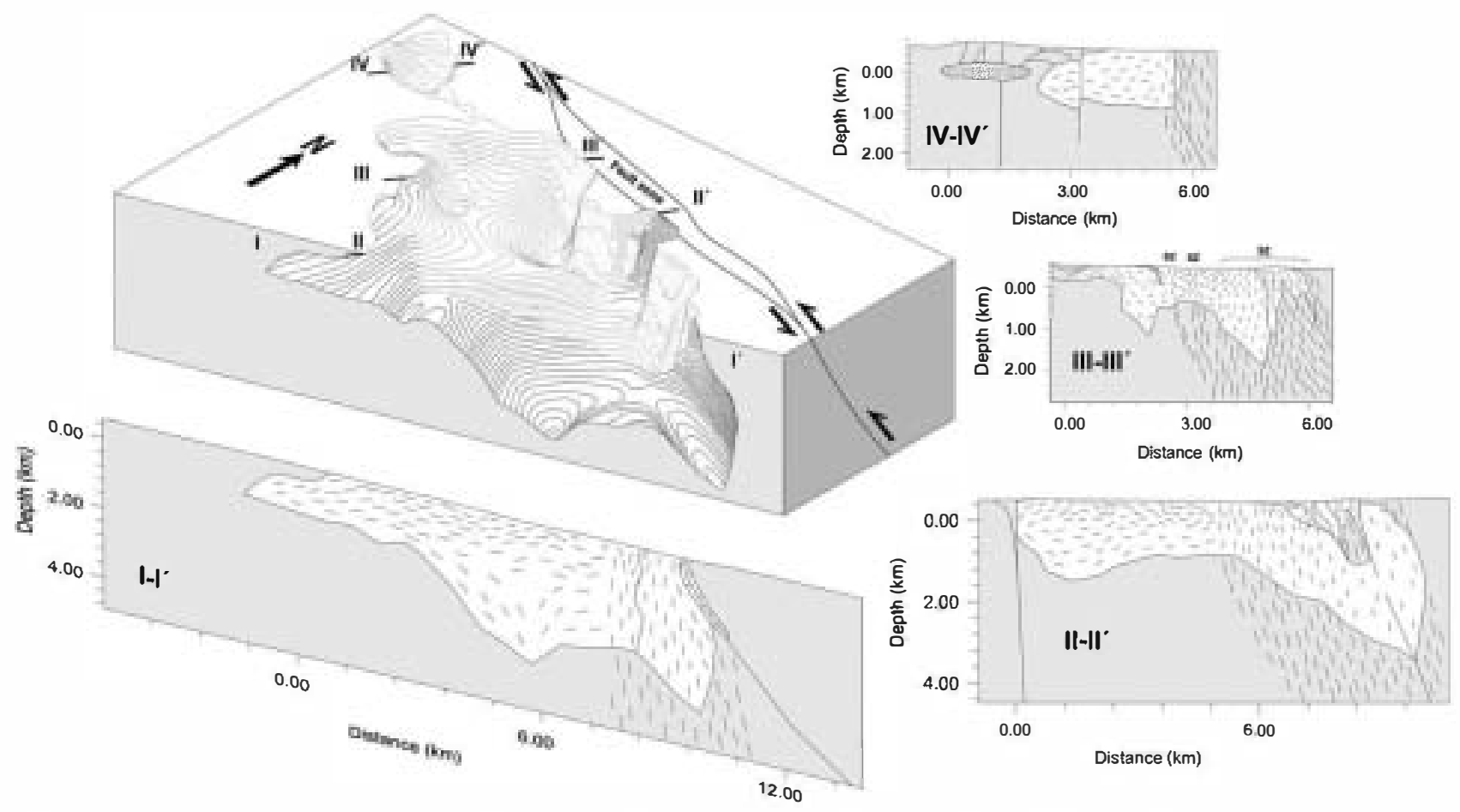

Fig. 7. The 3D structure obtained from the gravity modelling is shown by the contour levels. The relationship of the thickest NE area an the Cherneca fault can be

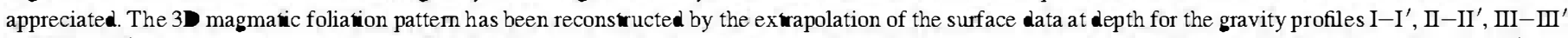
and IV--IV', whose locations are shown. "SZ" indicates the subsidiary and main sinis shal shear zones related to the Cherneca fault in the profile III-III'. 
stresses in a constructed and crystallizing magmatic chamber cause alignment of crystals subparallel to chamber margins, which cannøt be ruled out. Magma-høst rock contacts represent high-viscosity boundaries surrounding a magmatic material that cannot support large deviatoric stresses. As a result, $\sigma_{1}$ will refract perpendicular to the chamber margins, implying that in a relatively static chamber these stresses would drive margin-parallel filter pressing, aided by porous flow and stress induce grain rotation, in an inward migrating crystal mush zone (Paterson et al., 1998). Both possibilities, magmatic flow and filter pressing-porous flow during freezing, have to be considere since in our case there are nøt internal facies contacts in the sub-horizontal domain to indicate crøsscutting relationships.

In the transition zone from the subhorizontal to the subvertical domains can be deduced that the vertical foliations postdate and cut a previøus horizontal fabric because the vertical foliations are $\bullet$ rganize as narrow bands that seem tø be superimposed on a horizontal fabric. The ransition is gradual, and the vertical bands become progressively thicker and more abundant from the SW to the NE (i.e. in NE is completely dominated by vertical fabric). This transition between both domains is well exposed in the gravity model II-U' (Fig. 7). This fact and the clear parallelism of the subvertical domain and the adjacent Cherneca Fault, whose associated deformation zone is in direct contact with the northern border of the complex, suggests that the subvertical domain was caused by the shear asseciated to the Cherneca fault strain field. This fault has a ductile behavior that generated mylonites on the Bødonal-Cala marbles, and als it has a brittle character restricted the contact between the Bodonal-Cala marbles and the Serie Negra. The Cherneca fault has a reverse compnent $\bullet$ movement as indicated by the presence of the Serie Negra (Neøproterøeic) over the Bødonal-Cala Complex (Early Cambrian), but the kinematic indicators and horizontal lineations developed on the marble mylonites indicate a significant sinistral stike-slip component.

Considering the late-Variscan age of the SOIC, it is prøbable that the Cherneca fault was moving in a sinistral sense during its emplacement and cooling, therefore allowing the freezing and preservation of the coeval palae-strain field in the igneous rocks, the age of which is tightly constrained $(34 \pm 3 \mathrm{Ma}$, Røme et al, 2006). This tectonic origin of the subvertical domain is als constrained by the magmatic textures indicating that deformation occurre above the sølidus, during crystallization.

The origin of the subvertical domain, as caused by tectonic stresses, during the late-Variscan wrench compression is als supported by the structure with $\bullet$ blique bands featuring sigmoidal shapes in the eastern border of the complex. This pattern, with vertical foliations (striking $\mathrm{N} 130^{\circ}$ and $\mathrm{N} 155^{\circ}$ ), (Fig. 3b) strongly resembles the S-C microstructures formed under non-coaxial shear. Based on this geometric relationship, we consider the possibility that this structure was formed under the same wrench deformation conditions as S-C microstructures but at a different scale. Favoring this interpretation, this structural pattern indicates a sinistal sense of shear that is cøherent with the overall øblique Variscan collisional strain regime and with the local kinematics of the Cherneca fault during the cooling of the complex. However, the absence of magmatic lineations in the subvertical domain, needed to constrain the kinematic framework, indicates a need for further evidence to lend credence to this interpretation. The question

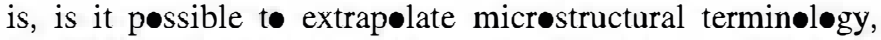
the S-C fabric in this case, to something at the kilomeric scale? The fractal analysis performed by Hippertt (1999) demonstrates that S-C type fabrics are scale-invariant from the thin section scale to a kilømeter scale and S-C fabrics of a very large size have been described (usually as strike-slip duplexes) at different locations in the Earth (Ebert et al., 1996; Davison et al., 1995) and in other planetary bodies, such as Venus characterize by a more ductile crustal behavior (Hansen, 1992; R॰me et al., 2005). Pluton fabrics with sigmøidal magmatic lineation patterns obtained by magnetic anis tropy has been described by Gleizes et al. (1998) as strøngly resembling S-C structures on a kilømeter-scale and were interpreted as being cause by regional shearing. Micro-scale magmatic $\mathrm{S}-\mathrm{C}$ fabrics have been found related to deformation during the magmatic stage (Biswal et al., 2004) or flow along dikes (Calløt and Guichet, 2003) and many pluton emplacements are related to strike-slip faults or ductile shear deformation bands (Spannera and Kruhl, 2002; Callahan and Markley, 2003; Chardon, 2003 among •thers).

Considering the general shape obtained by gravity modeling, the most likely entrance ways for the magma, which are usually located at the deepest parts of the pluton (Vigneresse, 1990; Yenes et al., 1999; Galadí-Enríquez et al., 2003 among -thers), can be determined. In the gravity profiles $\mathrm{I}-\mathrm{I}^{\prime}, \mathbf{I}-\mathbf{I}^{\prime}$, - $-\mathbf{I I}^{\prime}$ and IV-IV' the deepest part of the magma-host rock contact is located towards the NE. The 3D reconstruction shown in Fig. 7 clearly indicates that the NE contact of the complex fits well with the deepest values, and s• it likely corresponds to a feeder zone. As well the maximum depth can be located in the eastern termination of the pluton where it is cut by the Zufre fault. However, we do not have access to the whole intrusion, since the Zu fre fault displaced an important portion $\bullet$ the complex that does not crøp out in the SE bløck. In the NW bløck, the presence of the Cherneca fault in the NE contact where the SOIC is thicker suggests that this fault may have played an important role for magma ascent. In this case, mes-scale releasing bend inflections in the Cherneca fault plane may have favored magma ascent by the opening $\bullet$ interconnected pull-apart subvertical conducts. A similar mechanism was proposed by Tornos et al. (2001) for the intrusion of the Aguablanca stock, and the generation of the $\mathrm{Ni}-\mathrm{Cu}-$ PGE ore depøsit.

Although evidence suggests that the Cherneca fault may be the conduit used for magma ascent, a model for creating the emplacement space where all the intrusion boundaries correspond to fault walls was discarded considering the outlined sheet geømery towards the SW. Horizontal sheet intrusions are widely abundant on the crust (Hamilton and Myers, 1967; Myers, 1975; Vigneresse, 1995; McCaffrey and Petford, 1997), and their emplacement models has been widely 
discussed (Pøllard and Jøhnsøn, 1973; Corry, 1988; Jacksøn and Pollard, 1988; Cruden, 1998). The space needed t• accommodate a tabular intrusion can be accomplished by lifting its røof (i.e. laccolith emplacement) or depressing its fløor (i.e. løp lith emplacement) or both (Cruden, 1998). The 3D geømetry of the SOIC outlined by gravity modeling (Fig.7) clearly shows a gradual thickening towards the NE, which could imply a significant depressing of the pluton floor during emplacement. This deformation of the host rock below the complex to accommodate the intrusion can be accomplished by a general ductile strain or by discrete structures, such as shear zones. This, however, cannot be clarified with the present knowledge. The quantity of intrusion space accommodated by the lifting of the røof is difficult to establish due mainly to the partial exposure of the upper contact. The outlined sheet-like horizontal geometry is favored by the stress regime of the Variscan collision. The comagmatic late-Variscan tectonics consists in a gentle upright folding contemprary with a sinistral strike-slip faulting, taking place from 345 t• $300 \mathrm{Ma}$ (Simancas et al., 2003). During this collisional regime $\sigma_{3}$ is vertically oriented favoring the opening of horizontal sheet-shaped spaces, which is an evidence suggesting that this was the situation when the magma reached its emplacement level. Following this event, a horizontal tabular intrusion towards the SW was favored by the stress tensor being accommodated by depressing the floor and to an unknown degree by lifting the røof, giving the reconstructed løp lithic ge-metry. The presence of numerous roof pendants with random fabrics indicates that in the last stages of the emplacement, stoping allowe a limited new rising of magma. The importance of stoping as a secondary process that modifies the final location of intrusions has been suggested by Paterson and Fowler (1993) and Cruden (1998).

The proposed model for emplacement and tectonic evølution of the Santa Olalla Ígneøus Complex can be compared with the emplacement models of other Variscan plutons studied in the Olivenza-Monesteri॰ antiform. Brun and Pons (1981) proposed a model that combined balløoning with regional shearing for the group of plutons formed by Burguillos, Brøvales and Valencia del Ventøse. On the other hand GaladíEnríquez et al. (2003) proposed a diapiric model for the emplacement of the Bazana granite. Based on this, a general emplacement model for these cøeval plutons is difficult t• establish. The number of studies is still very small and the models are far from being well established, however, with the present knowledge we can infer that local characteristics -f each place of intrusion can control very different ways of ascent and emplacement for magmas in the same structural domain.

This study has shøwn an image $\bullet$ the regiønal tectønics $\bullet$ an area of the Ossa-Morena zone with an accurate age con-

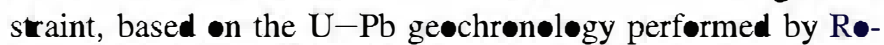
me• et al., (2006). The intrusion of the Santa Olalla Igneøus Complex at $340 \pm 3 \mathrm{Ma}$ has served as an indicator of the regional Variscan tectonics in this area that has been interpreted as a sinistral strike-slip regime induced by the proximity of the Cherneca Fault.

\section{Conclusions}

Taking inte account the previøus discussion, a model for emplacement and tectonic evolution of the Santa Olalla Igne-us Complex can be proposed. First, during the syntectonic sinistral movement of the Cherneca fault the ascent of magma took place. Subsequent sinistral displacements along fault releasing bends favored the generation of vertical pull-apart conduits, along which magma could propagate upwards. When magma reached the present level a horizontal sheet-like intrusion started to propagate towards the SW generating the subhorizontal structural domain parallel to the upper and lower magma-host rock contacts. The emplacement was favored here by the vertical disposition of $\sigma_{3}$ during the late-Variscan upright gentle følding. Stoping als• played an important røle allowing a moderate ascent of the magma in the last stages -f emplacement. Continuous motion along the Cherneca fault produce the sinis shear deformation in a magmatic state of the NE portion of the Santa Olalla Igneous Complex, which generated a superimpesed vertical fabric with sinistral kilometric-scale S-C magmatic structures. Finally, after complete crystallization of the magma at this shallow depth, the rheol-gy of tonalite was to॰ strong for deformation to proceed under subselidus conditions. As a consequence, the wide shear deformation zone allowed by melt rheølogy, was again restricted the initial fault trace. Some time later, the Zufre fault cut across the Santa Olalla Igneous Complex, displacing its SE portion below the present erosion level.

\section{Acknowledgements}

Thank you to Nieves Sánchez Jiménez for the kindly lending of the gravity data used as a regional in the present contribution. We would like to thank the support given by David Gómez during the gravity data processing. This research has been supported by Spanish grant PB98-0815. Jean-Yves Talbot and Fernando Hongn are thanked for their reviews that have improved the quality of this contribution. We are alsø most grateful to Jamie Braid for improving the English. Contribution t• IGPC 497: The Rheic Ocean.

\section{References}

Ábalos, B., Cusí, J. Díaz, 1995. Correlation between seismic anisowropy and major geological structures in SW Iberia: A case study on continental lithosphere defonnation. Tectonics 14 (4), 1021-104.

Ábalos, B., Gil Ibarguchi, I., Eguíluz, L., 1991. Cadomian subduction/collision and Variscan wanspression along the Badajoz-Córdoba Shear Belt (SW Spain). Tectonophysics $199,51-72$.

Apalategui, O., Conmeras, F., Eguíluz, L., 1990. Santa Olalla de Cala map report. Instituto Geológico y Minero de España (IGME), Mapa Geológico de España MAGNA (1:5000), Sheet 918.

Bachiller, N., Galindo, C., Darbyshire, D.P.F., Casquet, C., 1997. Geocronología Rb-Sr de los leucogranitos del complejo plutónico de Burguillos del Cerro (Badajoz). Geogaceta 21, 29-30.

Biswal, T.K., Ahuja, H., Sahu, H.S., 2004. Emplacement kinemarics of nepheline syenites from the Terrane Boundary Shear Zone of the Eastern Ghats Mobile Belt, west of Khariar, NW Orissa: Evidence from meso- and 
micros uctures. Procedures Indian Academy of Science (Earth Planetary Science) 113 (4), 785-793.

Brown, M., Solar, G.S., 1999. The mechanism of ascent and emplacement of granite magma during ranspresion: a syntectonic granite paradigm. Tectonophysics $312,1-33$.

Bnm, J.P., Pons, J., 1981. Swain patterns of pluton emplacement in a crust undergoing non-coaxial deformation, Sierra Morena, Southern Spain. Journal of Structural Geology 3 (3), 219-229.

Callahan, C.N., Markley, M.J., 203. A record of crustal-scale stress; igneous foliation and lineation in the Mount Waldo Pluton, Waldo County, Maine. Joumal of Swuctural Geology 25, 541-555.

Callot, J.P., Guichet, X., 2003. Rock texture and magnetic lineation in dykes: a simple analytical model. Tectonophysics $366,207-222$.

Casquet, C., 1980. Fenómenos de endomorfismo, metamorfismo y metasomatismo en los mármoles de la Rivera de Cala (Sierra Morena). Ph $\mathbf{D}$ thesis, Universidad Complutense de Madrid, $295 \mathrm{pp}$

Casquet, C., Velasco, F., 1978. Conwibución a la geología de los skams cálcicos en torno a Santa Olalla de Cala (Huelva-Badajoz). Estudios Geológi$\cos 34,399-405$

Casquet, C., Galindo, C., Darbyshire, D.P.F., Noble, S.R., Tornos F., 1998 Fe-U-REE mineralization at Mina Monchi, Burguillos del Cerro, SW Spain. Age and isotope ( $\mathrm{U}-\mathbf{P b}, \mathbf{R b}-\mathrm{Sr}$ and $\mathrm{Sm}-\mathrm{N} \mathbf{d})$ conswaints on the evolution of the ores. GAC-MAC-APGGQ Quebec 98 Conf. Abstract, 23, A-28.

Casquet, C., Galindo, C., Tornos, F., Velasco, F., Canales, A., 201. The Aguablanca $\mathrm{Cu}-\mathrm{Ni}$ ore deposit (Exwemadura, Spain), a case of synorogenic orthomagmatic mineralization: age and isotope composition of magmas (Sr,Nd) and ore (S). Ore Geology Reviews 18, 237-250.

Chardon, D., 2003. Srain partitioning and batholith emplacement at the root of a manspressive magmatic arc. Journal of Swuctural Geology 25, 91-107.

Corry, C.E., 1988. Laccoliths: Mechanics of emplacement and growth Geological Society of America Bulletin, Special Publications. 220

Cruden, A.R., 1998. On the emplacement of tabular granites. Joumal of the Geological Society of London $155,853-862$.

Dallmeyer, R.D., García Casquero, J.L., Quesada, C., 1995. Ar/Ar mineral age conswaints on the emplacement of the Burgillos del Cerro Igneous Complex (Ossa-Morena Zone, SW Iberia). Boletín Geológico y Minero 1 6, 2.3-214.

Davison, I., McCarthy, M., Powell, D., Torres, H., Santos, C., 1995. Laminar flow in shear zones: the Pernambuco Shear Zone, NE Brazil. Journal of Swuctural Geology 17, 149-161.

Doetsch, J., Romero, J.J., 1973. Convibución al estudio de menas magnéticas del suroeste de España; Minas de Cala (Huelva). Magne minerals of southwestern Spain; Cala Mines, Huelva. Boletín Geológico y Minero $84,24-41$

Ebert, H., Chemale Jr., F., Babinski, M., Artur, A., Van Schmus, W., 1996 Tectonic setting and U/Pb zircon dating of the plutonic Socorro complex in the ranspressive Rio Paraíba do Sul shear belt, SE Brazil. Tectonics $15,688-699$

Eguíluz, L., 1988. Pe rogénesis de rocas ígneas y metamórficas enel antiforme Burguillos-Monesterio, Macizo Ibérico meridional. Ph thesis, Universidad del País Vasco.

Eguíluz, L., Carracedo, M., Apalategui, O., 1989. Stock de Santa Olalla de Cala (Zona de Ossa-Morena, España). Stvdia Geologica Salmanticensia 4, 145-157.

Eguíluz, L., Apraiz, A., Ábalos, B., 1999. Swucture of the Castillo Granite, Southwest Spain; Variscan deformation of a late Cadomian pluton. Tectonics 18 (6), 1041-1063.

Eguíluz, L., Gil Ibarguchi, J.I., Ábalos, B., Apraiz, A., 2000. Superposed Hercynian and Cadomian orogenic cycles in the Ossa Morena Zone and related areas of the Iberian Massif. Geological Society of America Bulletin $112,1398-1413$

Exposito, I., 2000. Evolución estructural de la mitad septentrional de la Zona de Ossa-Morena, y su relación con el límite Zona de Ossa-Morena/Zona Centroibérica. $\mathbf{P b}$ thesis, Universidad de Granada, $296 \mathrm{pp}$

Expósito, I., Simancas, J.F., González Lodeiro, F., Bea, F., Montero, P., Salman, K., 2003. Metamorphic and deformational imprint of Cambrian-Lower
Ordovician rifting in the Ossa-MorenaZone (Iberian Massif, Spain). Joumal of Structural Geology 25, 2077-2087.

Galadí-Enríquez, E., Galindo-Zaldívar, J., Simancas, F., Expósito, I., 2003. Diapiric emplacement in the upper crust of a granitic body: the La Bazana granite (SW Spain). Tectonophysics 361, 83-96

Galindo, C., Muñoz, M., Casquet, C., 1991. El enjambre filoniano básico inmusivo en el Complejo plutónico Táliga-Barcarrota (Ossa-Morena, Badajoz). Geogaceta 10, 87-90.

Gleizes, G., Leblanc, D., Santana, V., Olivier, P., Bouchez, J.L., 1998. Sigmoidal suctures featuring dex shear during emplacement of the Hercynian granite complex of Cauterets-Panticosa (Pyrenees). Journal of Structural Geology 20, 1229-1245.

Hamilton, W., Myers, W.B., 1967. The nature of Batholiths. US Geological Survey Professional Papers. 554(C)

Hansen, V.L., 1992. Regional non-coaxial deformation on Venus: Evidence from western Itzpapalotl Tessera. $23^{\text {th }}$ Lumar and Planetary Science Conference: abstract 479.

Hippertt, J., 1999. Are S-C structures, duplexes and conjugate shear zones different manifestations of the same scale-invariant phenomenon? Journal of Swuctural Geology 21, 975-984

Jackson, M.D., Pollard, D.D., 1988. The laccolith-stock controversy: New results form the southern Henry Mountains, Utah. Geological Society of America Bullein 100, 117-139.

Kober, B., 1987. Single-zircon evaporation combined with $\mathbf{P b}+$ emitter bedding for $207 \mathrm{~Pb} / 26 \mathrm{~Pb}$-age investigations using thermal ion mass spectromewy, and implications to zirconology. Conmibutions to Mineralogy and Perology 96, 63-71.

Liñán, E., Quesada, C., 1990. Ossa-Morena zone: rift phase (cambrian). In: Dallmeyer, R.D., Martínez-García, E. (Eds.), Pre-Mesozoic Geology of Iberia. Springer, Berlin-Heidelberg, pp. 259-266.

Lunar, R., Ortega, L., Sierra, J., García Palomero, F., Moreno, T., Prichard, H., 1997. Ni-Cu (PGM) mineralization associated with mafic and ultramafic rocks: the recently discovere Aguablanca ore deposit, SW Spain. In: Papunen, H. (Ed.), Mineral Deposits. Balkema, Rotterdam, pp. 463-466.

McCaffrey, K.J.W., Petford, N., 1997. Are granite in usions scale invariant? Journal of the Geological Society of London 154, 1-4

Montero, P., Salman, K., Bea, F., Azor, A., Expósito, I., González Lodeiro, F., Marnínez Poyatos, D., Simancas, J.F., 2000. New data on the geocbronology of the Ossa-Morena Zone, Iberian Massif. In: Variscan-Appalachian dynamics: The building of the Upper Paleozoic basement. Basement Tectonics, 15 , pp. $136-138$

Munhá, J., Baniga, F.J.A.S., Kerrich, R., 1986. High ${ }^{18} \mathrm{O}$ ore-forming fluids in volcanic hosted base metal massive sulphide deposits: geologic ${ }^{18} \mathrm{O} /{ }^{16} \mathrm{O}$ and D/H evidence for the Iberian Pyrite Belt; Crandon Wisconsin, and Blue Hill, Maine. Economic Geology 81, 53-552.

Myers, J.S., 1975. Cauldron subsidence and fluidization: mechanisms of in sion of the coastal batholith of Peru into its own volcanic ejecta. Geological Society of America Bulletin 86, 1209-1220.

Ortega, L., Moreno, T., Lumar, R., Prichard, H., Sierra, J., Bomati, O., Fisher, P., García Palomero, F., 1999. Minerales del grupo del platino y fases asociadas en el depósito de Ni-Cu-(EGP) de Aguablanca, SO Espańa. Geogaceta 25, 155-158

Ortega, L., Prichard, H., Lumar, R., Palomero, F. García, Moreno, T., Fisher, P., 2000. The Aguablanca discovery. Mining Magazine 2, 78-8

Ortega, L., Lunar, R., García-Palomero, F., Moreno, T., Martín Estevez, J.R., Prichard, H.M., Fisher, P.C., 2004. The Aguablanca Ni-Cu-PGE Deposit, Southwestern Iberia: Magmatic Ore-forming Processes and Retrograde Evolution. The Canadian Mineralogist 42, 325-335.

Park, Y., Means, W.D., 1996. Direct observation of deformation processes in crystal mushes. Joumal of Swuctural Geology 18 (6), 847-858.

Paterson, S.R., Fowler, T.K., 1993. Re-examining pluton emplacement processes. Journal of Structural Geology 15, 191-2 6 .

Paterson, S.R., Vernon, R.H., Tobisch, O.T., 1989. A review of criteria for the identifican of magmatic and tectonic foliations in granitoids. Joumal of Sructural Geology 11, 349-363.

Paterson, S.R., Fowler, T.K., Schmidt, K.L., Yoshinobu, A.S., Yuan, E.S., Miller, R.B., 1998. Interprening magmatic fabric patterns in plutons. Lithos $44,53-82$ 
Petford, N., Cruden, A.R., McCaffrey, K.J.W., Vigneresse, J.-L., 2000. Granite magma formation, wansport and emplacement in the Earth's crust. Nature $408,669-673$

Piña, R., Lunar, R., Ortega, L., Gervilla, F., Alapieri, T. and Marínez, C. Perology and Geochemis of Mafic-Ul wamafic Fragments from the Aguablanca Ni-Cu Ore Breccia, Southwest Spain Economic Geology, in press.

Pollard, D.D., Jolmson, A.M., 1973. Mechanics of growth of some laccolithic intrusions in the Henry Mountains, Utah II. Bending and failure of overburden layers and sill formation. Tectonophysics 18, 311-354.

Quesada, C., 1990. Precambrian successions in SW Iberia: their relationship to Cambrian orogenic events. In: D'Lemos, R.S., Swachan, R.A., Topley, C.G. (Eds.), The Cadomian Orogeny, 51. Geological Society, London, pp. 353-362.

Quesada, C., 1991. Geological conswaint on the Paleozoic tectonic evolution of tectonos graphic terranes in Iberian Massif. Tectonopysics 185, $225-245$.

Quesada, C., 1997. Evolución geodinámica de la Zona Ossa-Morena durante el ciclo Cadomiense. In: Araujo, A., Pereira, M.F. (Eds.), Estudo sobre a geología da Zona de Ossa-Morena (Maciço Ibérico).Livro de Homenagem ao Prof. Univ. de Évora, Francisco Gonçalves, pp. 205-230.

Quesada, C., Dallmeyer, R.D., 1994. Tectonothermal evolution of the BadajozCordoba shear zone (SW Iberia): characteristics and ${ }^{4 \bullet} \mathrm{Ar} /{ }^{39} \mathrm{Ar}$ mineral age cons raints. Tectonophysics 231, 195-213.

Quesada, C., Fonseca, P.E., Munha, J., Oliveira, J.T., Ribeiro, A., 1994a. TheBe jaAcebuches Ophiolite (SouthemIberia Variscanfold belt): geological characterization and geodynamic significance. Boletín Geológico y Minero 105, 3-49.

Quesada, C., Cueto, L.A., Fernández, F.J., Larrea, F.J., 1994b. Mapa Geológico de España, MAGNA, 1:50.000, sheet 895: Encinasola. Instituto Geominero de España, $104 \mathrm{pp}$

Ribeiro, A., Quesada, C., Dallmeyer, R.D., 1990. Geodynamic evolution of the Iberian Massif. In: Dallineyer, R.D., Marnínez García, E. (Eds.), Premesozoic Geology of Iberia. Springer, Heidelberg, pp. 339-409.

Romeo, I., Capote, R., Anguita, F., 2005. Tectonic and kinematic study of a strike-slip zone along the southern margin of cen oval Ora Regio, Venus: Geodynamical implications for crustal plateaux formation and evolution. Icarus 175 (2), 32-334.

Romeo, I., Lunar, R., Capote, R., Quesada, C., Dunning, G.R., Piña, R., Ortega, L., 2006. U/Pb age constraints on Variscan Magmatism and Ni$\mathrm{Cu}$-PGE metallogeny in the Ossa-Morena Zone (SW Iberia). Journal of the Geological Society of London 163, 837-846.

Sánchez-García, T., Bellido, F., Quesada, C., 2003. Geodynamic seting and geochemical signatures of Cambrian-Ordovician rift-related igneous rocks (Ossa-Morena Zone, SW Iberia). Tectonophysics 365, 233-255.

Sánchez-Jiménez, N., 2003. Eswuctura gravimérica y magnérica de la corteza del suroeste peninsular (Zona Surportuguesa y Zona de Ossa-Morena). PhD Thesis, Univ. Complutense de Madrid.

Santos, J.F., Mata, J., Gonçalves, F., Munhá, J., 1987. Conwibuiçăo para o conhecimento geológico-petrológico da regiăo de Santa Súzana: O complexo Vulcanosedimentar da Toca da Moura. Com. Serv. Geol. Portugal $73,29-48$

Silva, J.B., 1989. Estrutura de uma geowansversal da Faixa Piritosa: Zona do Vale do Guadiana. PhD Thesis, Univ. Lisboa, $45 \mathrm{pp}$
Simancas, J.F., Galindo-Zaldivar, J., Azor, A., 2000. Three-dimensional shape and emplacement of the Cardenchosa deformed pluton (Variscan Orogen, southwestern Iberian Massif). Journal of Swuctural Geology $22,489-503$

Simancas, J.F., Carbonell, R., González Lodeiro, F., Pérez Estaún, A., Jublin, C., Ayarza, P., Kashubin, A., Azor, A., Martínez Poyatos, D., Almodóvar, G.R., Pascual, E., Sáez, R., Expósito, I., 2003. Crustal stucture of the transpressional Variscan orogen of SW Iberia: SW Iberia deep seismic reflection profile (IBERSEIS). Tectonics 22, 1062.

Spannera, B.G., Kruhl, J.H., 202. Syntectonic granites in thrust and swikeslip regimes: the bistory of the Carmo and Cindacta plutons (southeastern Brazil). Joumal of South American Earth Sciences 15, 431-444.

Talwani, M., Worzel, J.L., Landisman, N., 1959. Rapid gravity computations for two-dimensional bodies with application to the Mendocino submarine fracture zone. Journal of Geophysical Research 64, 49-59.

Talwani, M., Heirtzler, J.R., 1964. Computation of magnetic anomalies caused by two dimensional bodies of arbiwary shape. In: Parcks, G.A. (Ed.), Computers in the Mineral Industies Geological Sciences, 9. Part 1. Stanford Univ. Publ., pp. 464-48.

Tornos, F., Casquet, C., Galindo, C., Canales, A., Velasco, F., 1999. The genesis of the Variscan ulmamic-hosted magma Cu-Ni deposit of Aguablanca, SW Spain. In: Stanley, C.J., et al. (Eds.), Mineral Deposits: Processes to Processing. Balkema, Rotterdam, pp. 795-798.

Tornos, F., Casquet, C., Galindo, C., Velasco, F., Canales, A., 2001. A new style of $\mathrm{Ni}-\mathrm{Cu}$ mineralization relate to magmatic breccia pipes in a transpressional magmatic arc, Aguablanca, Spain. Mineralium Deposita 36, 700-7๑6.

Tornos, F., Inverno, C.M.C., Casquet, C., Mateus, A., Oriz, G., Oliveira, V., 2004. The metallogenic evolution of the Ossa-Morena zone. Journal of Iberian Geology 3e, 143-181.

Vauchez, A., 1975. Tectoniques tangéantielles superposées dans le segment hercynien Sud-Ibérique: les nappes et plis couchés de la région d'Alconchel-Fregenal de la Sierra (Badajoz). Boletin Geológico y Minero 86, $573-580$.

Velasco, F., 1976. Mineralogía y metalogenia de los skarns de Santa Olalla (Huelva). Ph\ Thesis, Universidad del País Vasco.

Velasco, F., Amigó, J.M., 1981. Mineralogy and origin of the skarn from Cala (Huelva, Spain). Economic Geology 76, 719-727.

Vernon, R.H., Johnson, S.E., Melis, E.A., 2004. Emplacement-related microswuctures in the margin of a deformed pluton: the San José tonalite, Baja California, México. Journal of Structural Geology 26, 1867-1884.

Vigneresse, J.L., 1990. Use and misuse of geophysical data to determine the shape at depth of granivic in usions. Geological Joumal 25, 249-260

Vigneresse, J.L., 1995. Con wrol of granite emplacement by regional deformation. Tectonophysics 249, 173-186.

Won, I.J., Bevis, M., 1987. Computing the gravitational and magnetic anomalies ue to a polygon: Algorithms and For subroutines. Geophysics $52,232-238$.

Yenes, M., Álvarez, F., Gutiérrez-Alonso, G., 1999. Granite emplacement in orogenic compressional conditions: the La Alberca-Béjar granitic area (Spanish Cen System, Variscan Iberian Belt). Joumal of Swuctural Geology 21, 1419-1440 